\title{
The Potential of Yacon Root (Smalanthus sonchifolius (Poepp.et Endl.) H.Robinson) as Prebiotics to Stimulate Growth of Lactobacillus plantarum B1765
}

\author{
Prima Retno Wikandari*, Ega Rocky Rafsanjani, Kharisma Nur Puspitasari \\ Chemistry Departmen, Faculty of Mathematics and Natural Science, \\ Surabaya, Indonesia \\ primaretno@unesa.ac.id
}

\begin{abstract}
Yacon (Smalanthus sonchifolius Poep p. Endl.) root is a source of inulin and fructooligosacharide (FOS) which potent as a prebiotic. Inulin and FOS hydrolyzed to glucose and fructans by inulinase which is secreted by probiotics bacteria and further metabolized to short chain fatty acids (SCFA) that were known as bioactive compound to prevent some degenerative diseases. This research observed the potential of yacon roots as prebiotics to stimulate the growth of L.plantarum B1765, a probiotic bacteria candidate, for some aspect including the number of lactic acids bacteria (LAB), pH, acidity and the profile of SCFA producing. Enumeration of LAB was done by total plate count using MRS medium + $\mathrm{CaCO3}$, acidity by titration, and the profile of SCFA were analyzed by HPLC. The growth of L.plantarum B1765 in yacon medium for 48 hours increased from $1,12 \times 106$ to $3,25 \times 108 \mathrm{CFU} / \mathrm{g}, \mathrm{pH}$ decreased to 3.28 , and total acids increased from $0.04 \%$ to $0.45 \%$. The yields of SCFA for 7 days of fermentation are propionic acid $1182.30 \mathrm{ppm}$, acetic acid $803.28 \mathrm{ppm}$ and butyric acid $375.41 \mathrm{ppm}$. Yacon roots are potential as prebiotics especially for the growth of L.plantarum $B 1765$ as the probiotic candidate.
\end{abstract}

Keywords - Yacon roots, L.plantarum B1765, prebiotic, probiotic, SCFA

\section{INTRODUCTION}

Prebiotics are defined as non-digestible food ingredients that selectively stimulate the growth and/or the metabolism of health-promoting bacteria in the intestinal tract, thus improving an organism's intestinal balance [1], [2]). Yacon root has potency as prebiotic because of their fructooligosacharides (FOS) and inulin containing substances. More than $90 \%$ of carbohydrates containing substances in yacon are FOS and inulin [3], [4]. Some lactic acid bacteria (LAB) strains could use FOS and inulin as growth medium [5], [6], [7] within the group of LAB, some of Lactobacillus plantarum strains had been studied had an ability to ferment inulin and FOS [5]. Inulin and FOS were hydrolyzed to glucose by inulinase which secreted by probiotic bacteria and further metabolized to SCFA, a bioactive compound which very useful to prevent some degenerative disease [8]. SCFAs are saturated aliphatic organic acids that consist of one to six carbons of which acetate $(\mathrm{C} 2)$, propionate $(\mathrm{C} 3)$, and butyrate $(\mathrm{C} 4)$ are the most abundant $(\geqslant 95 \%$ ) [9]. L. plantarum B1765 is an isolate of $\mathrm{LAB}$ of bekasam (traditional Indonesian fermented fish) isolate. Its potency as a probiotic candidate had been evaluated (data not published). In this study the potency of yacon as a prebiotics for some aspects including the growth of L.plantarum B1765, pH, acidity, and SCFA production were studied.

\section{METHODS}

\section{A. Culturing of L.plantarum B1765}

L.plantarum B1765 were obtaining from personal collection. It is the LAB isolate from bekasam (traditional fermented fish from Indonesia). The isolate bacteria from frozen glycerol and Man Rogosa Sharpe (Oxoid) (1:1) stock at temperature $2{ }^{\circ} \mathrm{C}$ was subculture twice. About $1 \%$ of isolate was inoculated to MRS broth (Oxoid) and incubated (Memmert) at $37^{\circ} \mathrm{C}$ for $20 \mathrm{~h}$ at anaerobic state. The suspension then was centrifuged (Eppendorf) for 15 minutes at $3500 \mathrm{rpm}$, supernatant were discarded and the pellet were suspended in $50 \mathrm{~mL}$ of $\mathrm{NaCl} 0.85 \%$ sterile used as a culturing starter of LAB bacteria for yacon pickle.

\section{B. Pickle yacon and samples preparation}

Yacon were harvested from Senduro, East Java, Indonesia. The roots with no physical damaged then was selected, peeled, washed and processed as described by [10] with some modification. Yacon roots were cut $\pm 1 \mathrm{~cm} \times 1$ $\mathrm{cm} \times 1 \mathrm{~cm}$ in size, and then approximately $200 \mathrm{~g}$ were soaked in a glass jar that contained about $500 \mathrm{~mL}$ of $3 \%$ brine $(\mathrm{NaCl}) .10 \%(\mathrm{~V} / \mathrm{W})$ of starter culture then was inoculated after brine fermentation for 2 hours, and fermented for 7 days at $37^{\circ} \mathrm{C}$. For sample preparation, about $10 \mathrm{~g}$ approximately of bacon pickles was homogenate aseptically in stomacher by add of $90 \mathrm{~mL}$ of $0.86 \% \mathrm{NaCl}$. Sample withdrawn at $0 \mathrm{~h}, 3 \mathrm{~h}, 24 \mathrm{~h}$ and $48 \mathrm{~h}$ for determination of number of $\mathrm{LAB}$, acidity and $\mathrm{pH}$, and only at $48 \mathrm{~h}$ for SCFA assay.

\section{Enumeration of total $L A B$}

Enumeration of LAB was done by modification method of [11] using enumerate the viable cells in the homogenate samples by serially diluted and plated aseptically using poured method on solid MRS agar (Oxoid) that contains 1\% $\mathrm{CaCO} 3$, and incubated anaerobically for $48 \mathrm{~h}$ at $37{ }^{\circ} \mathrm{C}$. 
LAB growth was expressed in colony forming units per milliliter (cfu/mL).

\section{SCFA analysis}

About $5 \mathrm{~mL}$ of homogenate sample was centrifuged at $8500 \mathrm{rpm}$ for 10 minutes. Supernatant was filtered using millex, then $20 \mu \mathrm{L}$ of filtrate injected into HPLC. The SCFA components of yacon pickle were detected by MethaCarb H Plus coulomb, flow rate of $0.6 \mathrm{~mL} /$ minute, equipped with photodiode array detector, coupled to spectrophotometer at $215 \mathrm{~nm}$ wave length. The mobile phase was $0.005 \mathrm{M}$ $\mathrm{H} 2 \mathrm{SO} 4$. SCFA profiles and lactic acids were determined qualitatively and quantitatively using standards of acetic acid, propionic acid, butyric acids and lactic acids from Sigma.

\section{E. Acidity and $\mathrm{pH}$ determination}

Acid total test was done by acid base titration using $\mathrm{NaOH} 0.1 \mathrm{~N}$ as a standart solution. $10 \mathrm{~mL}$ sample was dilution to $100 \mathrm{~mL}$ in a volumetric flask, then $20 \mathrm{~mL}$ sample solution was taken and put in an erlenmeyer flask, 2-3 drops of phenolphthalein were dropt as an indicator. The mixture then was titrated with $0.1 \mathrm{~N} \mathrm{NaOH}$ until the change of pink colors was happened. The volume of $\mathrm{NaOH}$ needed then was noted, and the acid total was represented as a lactic acid percentage. $\mathrm{pH}$ of samples was measured using Eutech $\mathrm{pH}$ meter.

\section{RESULTS AND DISCUSSIONS}

\section{A. Results}

1) Total LAB, acids production and $\mathrm{pH}$ of pickle yacon : The total $\mathrm{LAB}$, acid production and $\mathrm{pH}$ of yacon pikle at fermentation time is showed at Table 1.

TABLE I. TOTAL LAB, ACIDITY (\%) AND PH OF PICKLE YACON DURING THE FERMENTATION PROCESS

\begin{tabular}{|c|c|c|c|c|}
\hline No & $\begin{array}{c}\text { Fermentation } \\
\text { time (h) }\end{array}$ & $\begin{array}{c}\text { Total LAB } \\
\text { (CFU/mL) }\end{array}$ & $\begin{array}{c}\text { Acidity } \\
(\mathbf{\%})\end{array}$ & pH \\
\hline 1 & 0 & $1.12 \times 10^{6} \mathrm{a}$ & $0,044 \mathrm{a}$ & $6.15 \mathrm{a}$ \\
\hline 2 & 3 & $4.20 \times 10^{6} \mathrm{a}$ & $0.110 \mathrm{~b}$ & $5.14 \mathrm{~b}$ \\
\hline 3 & 24 & $6.90 \times 10^{7} \mathrm{~b}$ & $0.296 \mathrm{c}$ & $3.43 \mathrm{c}$ \\
\hline 4 & 48 & $3.25 \times 10^{8} \mathrm{c}$ & $0.452 \mathrm{~d}$ & $3.28 \mathrm{c}$ \\
\hline
\end{tabular}

During the fermentation process of pickle yacon using a culture starter of L.plantarum B1765, the number of LAB showed no significant changes until 3 hours fermentation, but increased sharply for $2 \log$ cycle from $1.12 \times 10^{6}$ $\mathrm{CFU} / \mathrm{mL}$ to $3.25 \times 10^{8} \mathrm{CFU} / \mathrm{mL}$ after 48 hours of fermentation. The acidity increased significantly, started from $0.044 \%$ at $0 \mathrm{~h}$ fermentation to $0.452 \%$ at the end of fermentation for $48 \mathrm{~h}$. Increasing of acidity was allowed by reducing of $\mathrm{pH}$. The $\mathrm{pH}$ reduced significantly from 6.15 to 3.43 during $24 \mathrm{~h}$ fermentation, but didn't show a significant reducing until $48 \mathrm{~h}$ fermentation.

2) Profil of SCFA : Analysis of SCFA profile was conducted using High Performance Liquid Chromatography (HPLC). SCFA containing in homogenate of extract yacon pikle for 7 days fermentation was evaluated. Figure 1 show the retention time of SCFA standard analysis by HPLC at
$14.590,16.648,19.253$ and 22.930 minutes for lactic acid, acetic acid, propionic acid and butyric acid standard respectively.

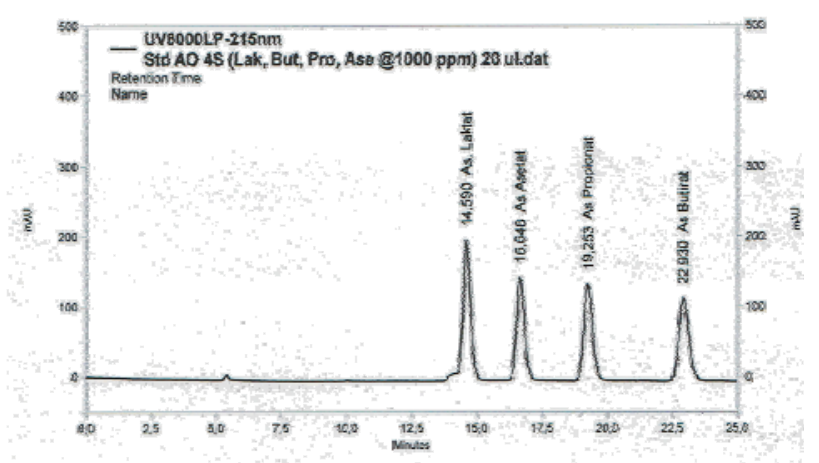

Fig. 1. Retention time of some SCFA standart at chormatogram of HPLC

The SCFA profiles of yacon pickle extract are showed in Fig.2. It could be seen from this figure that yacon pickle extract showed some retention times as the same as SCFA standard. It means that yacon pickle produced lactic acid, acetic acid, propionic acid and butyric acid.

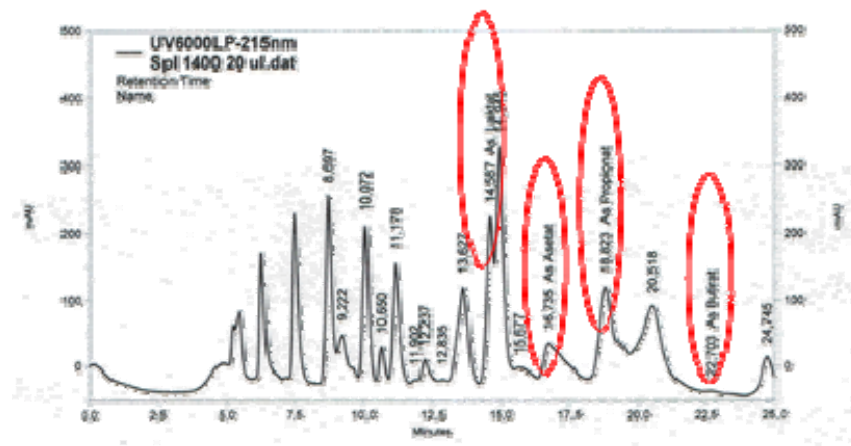

Fig. 2. The SCFA profile of yacon pickle fermented for 7 days.

The yield of SCFA containing in yakon pickled were analyzed quantitatively. The result showed that among the SCFA's containing, propionic acid produced in the highest level $1182.3 \mathrm{mg} / \mathrm{L}$, allowed by acetic acid $803.8 \mathrm{mg} / \mathrm{L}$, butyric acid $375,1 \mathrm{mg} / \mathrm{L}$ and lactic acid $371.01 \mathrm{mg} / \mathrm{L}$ as shown at Figure 3.

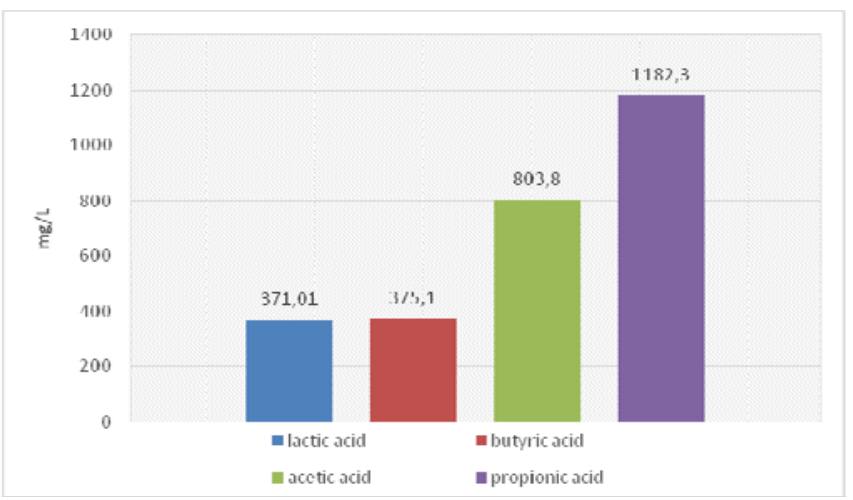

Fig. 3. The yield of SCFA containing in yakon pickled 


\section{B. Discussion}

The number of LAB was increased to $3.25 \times 10^{8}$ $\mathrm{CFU} / \mathrm{mL}$ during the fermentation process for $48 \mathrm{~h}$ of pickle yacon using L.plantarum B1765 as a culture starter. It attributed that yacon pickle as a good source of prebiotics especially for the growth of L.plantarum B1765, a prebiotic candidate that was isolated from bekasam. The growth of $\mathrm{LAB}$ followed by increasing acidity and reducing $\mathrm{pH}$ to 3.43. This is suported with the study of characterization microbial diversity in yacon fermentation with $2 \% \mathrm{NaCl}$ spontaneously, that the number of LAB increasing to $10^{8} \mathrm{CFU} / \mathrm{g}$ for 3 days of fermentation and reduced gradually after 7 days of fermentation [12].LAB could metabolized yacon which was showed by drops the $\mathrm{pH}$ to 3.7 [13] Yacon roots is rich with inulin and FOS, both of these compounds couldn't be hydrolyzed by digested enzyme, but they fermented by the microbial at intestinal tract. Lactobacillus plantarum is a Gram positive lactic acid bacterium commonly found in fermented food and in the gastro intestinal tract [14]. It is an evident that FOS and inulin in yacon roots were metabolized by L.plantarum B1765 yielding some SCFA that increasing the acidity and reducing $\mathrm{pH}$ in yacon pickle. This agreed with some study that L.plantarum could metabolize saccharide including FOS and inulin [5],[6],[7]Fermentation of pickle yacon by starter culture of L.plantarum B1765 produced lactic acids and some SCFA including propionic acids, acetic acids and butytic acid. Profile of SCFA showed that propionic acids were the highest level of SCFA that were found in pickle yacon. In fermentation process, fructans will be degraded into glucose and fructose polimer by $\beta$-fruktofuranosidase at $\alpha$ (1-2) glycoside bond [15]. Fructose polymers then were hydrolyze by inulinaseat $\beta(2-1)$ bond, glycolized to phosphoenolpyruvate (PEP) and metabolized to SCFA furthermore [5],[8]. This studied was supported by some research. L. plantarum WCFS1 from human saliva has $\beta$ Fructofuranosidase that attacked linkage of $\beta-2,1$ [6]. $L$. plantarum ST-III Kimchihas $\beta$-Fructofuranosidase which attacked linkage of $\beta-2,1 ; \beta-2,6$ [16]. From this research we inform that pickle yacon is a good source of prebiotics, especially for the growth of L.plantarum B1765, a probiotic candidate that was isolated from bekasam. In future days this pickled has a big chance to develop as an symbiotic agent and health food because some benefits i.e. promoting health bacteria in intestinal track, and SCFA producing is useful to prevent some degenerative diseases.

\section{REFERENCES}

[1] Gibson,G.R., H.M Probert, J.Van Loo, R.A Rastal, M.B Roberfroi. "Diatery modulation of the human colonic microbiota: updating the concept of prebiotics". Nutr.Res.Rev, 2004, 17:259-275.

[2] Reid, G., M.E., Sanders,H.R. Gaskin, G.RGibson, A. Mercevier, R. Rastall, M.Roberfroid,I. Rowland, C. Cherbut, T.Klaenhammer. "New scientific for probiotics and prebiotics". J.Clint.Gastroenterol, 2003, 37 : 105-118.

[3] Polreich, S. Establishment of a classification scheme to structure the post-harvest diversity of yacon storage roots (Smallanthussonchifolius (poepp, \&endl) H. Robinson). Lima: Peru University of Kassel, 2003.

[4] Campos, D., I.B. Pallardel, R. Chirinos, A.A. Galvez, R. Pedreschi. "Prebiotic effects of yacon (SmallanthussonchifoliusPoepp. \&Endl), a source of fructooligosaccharides and phenolic compounds with antioxidant activity". Food Chemistry, 2012, 135: 1592-1599.

[5] Kaplan H., R.W. Hutkins. "Fermentation of fructooligo-saccharides by lactic acid bacteria and bifidobacteria". Applied and Environmental Microbilogy., 2000, 66 (6):2682- 2684.

[6] Saulnier D.M.A, D. Molenaar,G.R. Gibson,W.M. de Vos, S. Kolida. "Identification of prebiotic fructooligo-saccharide metabolism in Lactobacillus plantarum WCFS1 through microarrays". Applied and Environmental Microbiology, 2007, 73 (6): 1753-1765.

[7] Velikova P.V., G.I. Blagoeva, V.G. Gotcheva, P.M. Petrova. Novel Bulgarian Lactobacillus strains ferment prebiotic carbohydrates. J. BioSci. Biotech. 55-60, 2014.

[8] Hijova, E., Chmelarova, A. "Short Chain Fatty Acids and Colonic Health”. BratisLekListy, 2007, 108 (8):354-358.

[9] Nicholson, J. K., Holmes, E., Kinross, J., Burcelin, R., Gibson, G.,Jia, W., \&Petterson, S. "Host-gut microbiota metabolic interactions". Science, 2012, 336:1262-1267.

[10] Panda, Smita H., P, Mousomi, R, Ramesh C. "Lactic acid fermentation of sweet potato (Ipomoea batatas L.) Into Pickles". Journal of Food Processing and Preservation, 2007, 31: 83-101.

[11] Nwchukwu, E., O.K, Achi, I.O Ijeoma. "Lactic acid bacteria in fermentation of cereal for the production of indigenous Nigerian foods". Afican Journal of Food Science and Technology, 2010, 12: 021-026.

[12] Reina, L.D., L.M Peres-Diaz, F.Breidt, M.A Azcarate-Peril, E.Medina, N.Butz. "Characterization of the microbial diversity in yacon spontaneous fermentation at $20^{\circ} \mathrm{C}$ ". International Journal of Food Microbiology, 2016, 203:35-40.

[13] Reina, L.D., Guija, E., Reategui, O., Parodi, C., Encizo, J. "Yacon preservation by naturalfermentation". Cientifica6, 2009, (3), 221-231.

[14] Arasu, M.V., N.A. Al-Dhabi, S.Ilavenil, K.C.Choi, S.Srigopalram. "Invitro importance of probiotic Lactobacillus plantarum to medical field”. Saudi J.Biol.Sci, 2016, 23(1):S6-S10.

[15] Rahman, S. M. M. Mahbubur., Sen,Palash Kumar., Hasan, M. Fida., Miah,M.A. Samad., Rahman,M. Habibur. "Purification and Characterization ofInvertase Enzyme from Sugarcane". Pakistan Journal of Biological Sciences, 2004, 7 (3). 340-345.

[16] Chen, C., F.Zhou, J.Ren, Y.Dong, Z.Wu, W.Chen. "Cloning expression and functional validation of a-beta fructofuranosidase from Lactobasillusplantarum". Process Biochems, 2014, 49:758-767. 